\title{
The Establishment of the System for Cultivating Innovative and Pioneering Talents in Business Administration under the Background of Internet+
}

\author{
Han Bin ${ }^{1}$ and Kong Jijun ${ }^{2}$ \\ (1 Yunnan Academy of Governance, Kunming, Yunnan 650111; 2 Yunnan Forest Academy, \\ Kunming, Yunnan 650223)
}

\begin{abstract}
Keywords: Business Administration; Internet plus; Innovation and Entrepreneurship; Talent Cultivation
\end{abstract}

\begin{abstract}
Under the background of Internet plus, the development of innovation and entrepreneurship, business and management professionals are also facing the urgent need of how to inject "innovation and entrepreneurial elements" to "upgrade" their own quality structure. Objectively speaking, in this regard, business management professionals have their own discipline advantages in terms of strategic thinking, market research, creative and innovative design, project analysis, investment and financing management, team building, organization management, and marketing planning. How to integrate the teaching method with innovation and entrepreneurship practical ability as the core elements in the professional knowledge and skills teaching system becomes the key point. This paper studies the cultivation of innovative and entrepreneurial talents in the context of Internet plus, so as to provide valuable reference for the cultivation of innovative and entrepreneurial talents in business administration.
\end{abstract}

\section{Introduction}

With the acceleration of Internet plus and economic and social development, the cultivation of college students' innovative entrepreneurship and ability is becoming increasingly important. Whether it is from the study and creation of professional theoretical knowledge or the practice of innovation, entrepreneurship, and employment, college students' innovative entrepreneurship and ability have become indispensable elements in the overall quality of college students. In the instructions for the first China Internet Plus College Students Innovation and Entrepreneurship Competition finals, Premier Li Keqiang pointed out: College students are the driving force for implementing innovation-driven development strategies and promoting popular entrepreneurship and innovation, and they must earnestly study and master more knowledge. , but also to join in innovation and entrepreneurship, improve the ability to practice. The knowledge areas studied by business management students are most closely related to innovation and entrepreneurship, and are the most active groups in the practice of innovation and entrepreneurship. Therefore, it is particularly important to understand the undergraduates' abilities of innovation and entrepreneurship and the current state of spiritual training in business administration, to better play their role in innovation and entrepreneurship practices, and to promote the overall performance of social innovation and entrepreneurship. Judging from the development of higher education, it is clear that innovation and entrepreneurship practice requires the entrepreneurial spirit and ability of undergraduate business management students, then explores the path and model for the cultivation of innovative entrepreneurship and ability of college graduates. This is the only way for the reform of business management talents.

\section{The Requirements of Innovation and Entrepreneurship and Ability of Business Administration Undergraduates in the Internet+Background}

The innovation and entrepreneurship strategy puts forward new requirements for the entrepreneurial spirit and ability of undergraduates in business administration, including the following aspects. 


\section{Courage to Innovate and Dare to Start a Business}

College students are learners, communicators, and producers of modern scientific knowledge. They are also the main force for innovation and entrepreneurship. In the current era of rapid technological development and surging waves of innovation, college students are bound to change their traditional attitude of "reading as one who reads only the Sages", fundamentally changing their learning methods and attitudes, grasping knowledge innovation and evolutionary trends, daring to challenge the authority, breaking the tradition, puting forward new ideas, createing new knowledge as well. While innovating and disseminating new theories and new knowledge, we must also actively participate in the practice of innovation and entrepreneurship, enhance practical ability, dare to connect the knowledge and practice we have learned, accept the test of practice, and further extend and expand entrepreneurship through practice.

\section{Advocating Success, Tolerance for Failure}

While pursuing the trend of the era of innovation and entrepreneurship, college students have established their ambitious goals and pursued their idols of worship, forming aspirations and determinations for success. However, due to the traditional concept of "winner takes all", people tend to focus on and recognize success, but ignore and laugh at failure. Innovative entrepreneurs are the most lonely and most in need of understanding because they have to face and explore the many uncertainties of the unknown world on their own. It is best to understand that they are tolerant to failure. For decades, Silicon Valley has continuously created the most dazzling corporate and entrepreneurial stars of this era. It is important to understand and even respect the failures.

\section{Strengthen the Profession and Highlight Applications}

The study of professional knowledge is the main task and fundamental responsibility of college students in business administration. It is related to the direction and quality of future career development. Whether it is from the theory of labor division or the interest and specialty of college students, choosing one or a few specialized fields for professional study and exploration is the best way for university students to learn and develop. Although some scholars and practitioners have proposed a wide-caliber, compound-type talent training model and implemented it in practice, it has been proved that undergraduate students should be professional in their study and be deeply explored in specialized fields to become "experts", so,only in the future can we make achievements in the practice of innovation and entrepreneurship.

\section{Discover Opportunities and Build Networks}

Innovation and entrepreneurial activity is a process in which innovative entrepreneurs acquire the necessary innovation and entrepreneurial resources and elements through the construction of a network, and through this network, enhance the ability and performance of innovation and entrepreneurship. Therefore, in addition to accumulating and optimizing its own resources, it is extremely important to identify the external environment and explore various opportunities in the environment. Undergraduate entrepreneurship in China is mainly "opportunity-based entrepreneurship", not because of the pressure of survival. On the basis of exploring and grasping opportunities for innovation and entrepreneurship, college students should also learn to build innovative entrepreneurial networks, integrate various innovative and entrepreneurial resources, form teams, and form a powerful combination of innovation and entrepreneurship.

\section{The Status Quo of Talent Cultivation in Business Administration Innovation and Entrepreneurship}

Although the business administration majors of many colleges and universities all pay attention to the construction of innovation and entrepreneurship education to varying degrees, there are still some deficiencies in the integration of innovation and entrepreneurship education.

The Professionalism of Innovation and Entrepreneurship Teaching Activities is not Good

On the whole, colleges and universities are mostly concentrated in sports and sports activities. The practice of integrating innovation and entrepreneurial quality training cannot satisfy the needs of undergraduates majoring in business administration. Some projects have relatively high restrictions on registration. Although they have objectively improved the quality of the project, they 
will encounter a lot of problems in the promotion. In addition, some teachers have a narrow and one-sided understanding of innovation and entrepreneurship teaching activities, and believe that activity practice is subordinate to theoretical teaching and skills teaching, and does not raise it to the height of "innovation and entrepreneurship education". If there is no effective instruction of teachers, many innovative and entrepreneurial teaching activities will lack professionalism, form but no substance, and the negative effects such as disjointness from theoretical courses, incompatibility of content and entrepreneurial ability, and poor exercise effects of college students.

Some Activities Lack the Support of Teachers with Innovative Entrepreneurial Knowledge and Skills

For example, the "Undergraduate Innovation and Entrepreneurship Training Program" is carried out in various universities and colleges, and the categories of declarations are diversified. Students of different majors and different levels of study can apply for corresponding projects according to their own specialties. In this way, the students' enthusiasm for participation increases, and the number of participants is large. However, colleges and universities can not match the needs of instructors. On the one hand, they cannot meet the demand. One teacher may direct several teams. On the other hand, not every instructor can meet the requirements of innovation and entrepreneurship, which results in unsatisfactory guidance effect and is detrimental to the growth of students' innovation and entrepreneurship ability.

\section{There are Still Deviations in the Direction of Personnel Training}

At present, colleges and universities in the exploration of building a system for cultivating business management professionals have, on the whole, still failed to systematically reflect the structural characteristics of innovation and entrepreneurial talents, and are still focusing on theoretical teaching. In terms of practical ability teaching, it is still biased towards cultivating post knowledge and skills, that is, to focus on cultivating students' skills training for future jobs in a subtle manner, and lacking training for undergraduate students in the process of innovation and entrepreneurship. At the same time, colleges and universities are neglecting to guide students' understanding of the real social environment. Even for students majoring in business administration, it is difficult for students to help students gradually and objectively and accurately understand the entrepreneurial opportunities available in the current society through systematic professional teaching processes. Their entrepreneurial thinking is more limited. Some students' entrepreneurial projects are hard to get out of school, which has a lot to do with their limited vision of entrepreneurial projects.

\section{The Construction of Talent Cultivation Mechanism for Innovation and Entrepreneurship in Business Administration under the Background of Internet and Internet}

Unlike the future professional managers in the traditional sense of the Internet and the background of innovation and entrepreneurship training in the Internet, the training system for business management professionals that highlights the orientation of innovation and entrepreneurship should closely follow the quality characteristics of innovation and entrepreneurial talents. In terms of training specification positioning, training program design, training mode selection, and combination of teaching methods, adjustments and optimization should be made accordingly to reflect the basic requirements for innovation and entrepreneurship.

\section{Training Specifications}

Training specifications refer to the talents and specific requirements for cultivating what kind of knowledge, abilities, and qualities. Under the background of popular entrepreneurship and innovation and social development, according to the objectives of personnel training objectives and quality model characteristics, the training specifications for business management professionals should be determined to meet the needs of enterprise entrepreneurship and innovation competition, with comprehensive innovation strategic thinking and mastery Entrepreneurial business management talent who plans, organizes, and implements basic capabilities and can support the company's continuous innovation and re-entrepreneurship.

Such talents should have three structures; knowledge structure: including basic knowledge of the 
public, basic knowledge of economy and management, basic knowledge of entrepreneurship, etc. skill structure: including professional and technical capabilities, creativity and project planning capabilities, organizational and leadership skills, and interpersonal skills. Information collection and analysis capabilities, resilience, and risk forecasting capabilities. Literacy structure: Including initiative, market sensitivity, willpower, emotional control, innovation, pioneering spirit, frustration, decision-making and so on.

\section{Training Plan}

The training program is based on the orientation of personnel training objectives, takes the talent ability and quality requirements as the core, and systematically constructs a systematic curriculum teaching form. Under the situation of innovation and entrepreneurship, the training program for business administration professionals should focus on the basic requirements for the quality model of innovative entrepreneurial talents, then it should contribute to the realization of the original intention of pioneering, combat-oriented entrepreneurial and operational management talents. The professional literacy cultivation of innovation and entrepreneurship should be carried out in every aspect of classroom teaching and practice design inside and outside class. Correspondingly, the curriculum system should also be constructed from the two parts of theoretical knowledge and method system, practice and simulation training system. The theoretical knowledge and method system curriculum can be divided into five modules: general knowledge knowledge modules, including knowledge of Marxist principles, English, advanced mathematics, sports, and College Chinese; basic knowledge modules of disciplines, including management, marketing, and economics Studies, Finance, Accounting, Business Law, Organizational Behavior, etc.

\section{Training Mode}

In the training mode, it is proposed to strengthen the students' ability to innovate and establish entrepreneurship. Around the two levels of "teaching" and "learning", based on the construction of the innovation and entrepreneurship training platform inside and outside the school, we will gradually form a fusion of "theory, experiment, training, "1 $+2+\mathrm{N}$ ", a business-management professional integrated with practical teaching, is an innovative entrepreneurial talents training model.

The so-called "1" refers to the core of the goal of training innovative talents. Under the current situation, in the goal of personnel training, we should highlight "thick foundation, strong ability, and re-use" .From the system's management basic thinking training, practical skills training and innovation ability training, we will cultivate multi-disciplinary, applied, innovative and entrepreneurial outstanding management talents.

The so-called "2" emphasizes the mutual matching and benign interaction under the premise of mutual innovation of "professor" and "learning". Under the background of innovation and entrepreneurship education, the "professor" should be different from the traditional mode of "answering doubts", which is reflected in the quality structure of the teaching staff itself. Only highly educated, refined theories, and good at scientific research are far from meeting the burden of training. The requirements for the responsibilities of creative and entrepreneurial business management professionals must also have corresponding innovation and entrepreneurship practical experience or be familiar with the company's operational operations, and can give students practical guidance in innovation and entrepreneurship training or practice from a practical perspective.

The so-called "N" is to actively construct a variety of forms of practical teaching facilities for innovation and entrepreneurship inside and outside schools, and to promote the development of a series of related campus activities in the second classroom.

\section{Summary}

Training innovative and entrepreneurial talents adapted to the development of modern society under the background of the Internet+ is an important direction of the education reform of the business administration at this stage. It is necessary to systematically and objectively adjust, innovate, and reform the existing training system for business management professionals in many aspects such as the planning and design of training specifications, training programs, and training models. Among 
them, scientific understanding and grasping the basic quality requirements of the double creative business management talents are the basis for advancing education reform, while practicality, practicality, participation, and diversity should be embodied in the whole process in teaching content design, teaching resource integration, and teaching method innovation. It is very challenging to reconstruct the innovation and entrepreneurial business management professional training system. The research in this article is only a preliminary exploration and reveals only the tip of the iceberg of this innovation and entrepreneurship system project. More valuable findings need to be further studied by many scholars concerned with double-creation education.

\section{Reference}

[1] Malik T.Is Patent-or Non-Patent Based Alliance an Effective Mechanism in University-Industry Biotechnological Innovation Diffusion?[J]. 2007.

[2] Chen J, Chen P S. Exploration on "Innovation-Creativity-Entrepreneurship" Personnel Cultivation in Vocational Colleges__ A Case of Yiwu Industrial and Commercial College[J]. Vocational Education Research in Xinjiang, 2013.

[3] Castaño-Martínez M S. Product innovation and R\&D policy: the case of the transformation industries in developed and developing[J]. International Entrepreneurship \& Management Journal, 2012, 8(4):421-436.

[4] Nunes Gimenez A M, Carneiro A M. Journal of Technology Management \& Innovation[J]. Journal of Technology Management \& Innovation, 2014.

[5] Dk A. Strategies for Innovation and High Growth Firm Development[J]. Aarhus University.

[6] Davey T, Rossano S, Sijde P V D. Does context matter in academic entrepreneurship? The role of barriers and drivers in the regional and national context[J]. Journal of Technology Transfer, 2016, 41(6):1457-1482.

[7] Szalavetz A. Innovation in Hungary - The Impact of EU Accession and Integration into Global Value Chains[J]. International Journal of Management \& Economics, 2014, 42(1):40-59.

[8] Kurpayanidi K, Muminova E, Paygamov R. Management of innovative activity on industrial corporations[J]. 2015.

[9] Nielsen K. Human capital and new venture performance: the industry choice and performance of academic entrepreneurs[J]. Journal of Technology Transfer, 2015, 40(3):453-474.

[10] Dutz M A, O'Connell S D, Troncoso J L. Public and Private Investments in Innovation Capabilities: Structural Transformation in the Chilean Wine Industry[J]. Policy Research Working Paper, 2014, 23(31):5301-5315.

[11] Low A, Muegge S. Keystone Business Models for Network Security Processors[J]. Technology Innovation Management Review, 2013:25-33.

[12] Jurczykbunkowska M. Concept of managing front end phase of innovation process[J]. Management \& Production Engineering Review, 2011, 2.

[13] Gallouj F. Service: innovation, performance and public policy[J]. Working Papers, 2012.

[14] Munoz J M, Welsh D H B, Chan S H, et al. Microenterprises in Malaysia: a preliminary study of the factors for management success[J]. International Entrepreneurship \& Management Journal, 2015, 11(3):673-694. 